\title{
THE COMPETENCE OF THEATRE AUDIENCES IN FIFTH- AND FOURTH-CENTURY ATHENS*
}

\begin{abstract}
After dismissing various possible approaches to the question of audience competence in fifth- and fourthcentury Athens, this article proposes to tackle this important and notorious problem with a novel strategy that is not 'top-down' but 'bottom-up', starting with spectators rather than plays and focusing on the bottom-line of expertise which can be taken to be shared by the majority of audience members. An umbrella-notion of 'theatrical competence' is established before two central characteristics of drama performed in Athens are exploited: the participation of spectators in the citizen-chorus at the Great Dionysia, and the implications for the competence issue of frequent exposure to an art form which is as formally conservative as preserved Attic drama. What emerges is a model of stratified decoding by spectators (élite and non-élite) who share a considerable level of theatrical competence. In a final step, this model is applied to a number of case studies taken from fifth-century comedy.
\end{abstract}

\section{I. (RE)FRAMING THE PROBLEM}

How competent were the audiences of classical Greek drama? Did they sense and appreciate the quality of the plays they saw, some of which are today widely regarded as masterworks of Western literature? Would they be able to distinguish the mediocre from the good, and the good from the outstanding (bearing in mind that plays like Clouds or the trilogy containing Medea were not awarded first prize)?

These questions should not be discarded lightheartedly. In the history of art there have been numerous audiences who, for all we know, failed in part or even completely to gauge the extent to which an artist surpassed the contemporary paradigm and excelled in the craft. Shakespeare, Bach and Mozart immediately come to mind, and the list could be much extended. 'Some day they will understand' is the anecdotal response attributed to the ailing Beethoven on his sick bed when informed of the uncomprehending reception with which one of his late string quartets was met. The Romantic notion of the unrecognized genius can even turn lack of appreciation during the artist's lifetime into something of a prerequisite for distinction. Van Gogh is a model case for such post-mortem iconization.

As far as fifth-century Athens is concerned,' any enthusiastic attempt to postulate a universally sophisticated audience is quickly nipped in the bud by a single remark in Aristotle's Poetics which makes caution the order of the day. In a passage concerned with the choice and construction of the plot he maintains (1451b23-6):

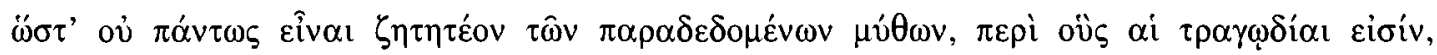

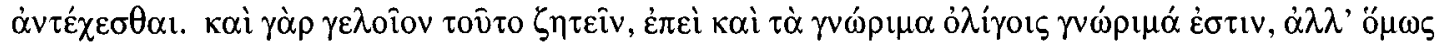

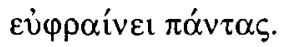

Hence there is no need to adhere at all costs to the traditional stories, around which tragedies are constructed. For to try to do this would be ridiculous, since even the well-known material is well-known only to a few, but nevertheless delights all.

The stories of Alcmaeon, Oedipus, Orestes, Meleager, Thyestes, Telephus, on which tragedy focuses time and again, ${ }^{2}$ are 'well-known only to a few': while in its crass form (which audi-

* I wish to thank Mark Griffith and the anonymous referees for helpful criticism.

1 Discussions are Römer (1905); Ehrenberg (1951) 27-37; Harriott (1962); Gelzer (1970) 1531-8; Gould and Lewis (1988) 275-8; MacDowell (1995) 16-26; Csapo and Slater (1995) 286-305; Seidensticker (1996) 33-5; Pelling (2000) 133-40; Wilson (2000b). When in 1972

Kenneth Dover prominently placed a full-page picture of a shepherd at the beginning of his Aristophanic Comedy 'to help us imagine the people who constituted the greater part of Aristophanes' audience', he was implicitly militating against any attempts at idealization.

2 Arist. Poetics 1453a17-22 and 1454a9f. 
ences? and how would someone like Aristotle know in the first place?) this statement clearly smacks of intellectual snobbery and aristocratic bias, discarding it in total would require a leap of faith few would (or should) be prepared to make. Most will concur that Aristotle's perception - telling as it is as an intellectual construct in itself - must have some basis in the reality of playgoing, at least in the fourth century. Aristotle's testimony gains credibility on the grounds that his take on theatre audiences is, by comparison with that of Plato, remarkably less polemical and more nuanced. While the notion of a diverse, hence partially base, audience forcing high-flying playwrights to adapt downwards is aired, ${ }^{3}$ Aristotle will even endorse the view that a mass audience (oi $\pi \circ \lambda \lambda \lambda^{\circ}$ ) is a better judge of musical and poetic competitions since an assessment based on more people's judgements is more complete ( $\pi \alpha \dot{v} \tau \tau \varepsilon \zeta \delta \dot{\varepsilon} \pi \alpha \dot{\alpha} v \tau \alpha$, as Aristotle concisely puts it). ${ }^{4}$ If anything, the remark from the Poetics should be good enough evidence to turn audience competence into a problem. There is no basis for constructing super-competent audiences who will collectively pick up on, for instance, a play's position within an inter-textual nexus of dramatic and non-dramatic story-telling (the sort of situation Aristotle refers to in the passage quoted above). And it would be rash and unsound to infer without further thought from the unquestionable complexity of Athenian drama an audience with a collective and all-round sophistication to match.

In addition, Aristotle's remarks are somewhat thrown into perspective by considering how inter-textual (or rather inter-performative) and, broadly speaking, mythological competence can be activated. Suffice it in this context to point to the one such instance which is not only the most notorious but also closest in kind to the situation invoked by Aristotle's remark. This is the recognition scene in Euripides' Electra (487-584). ${ }^{5}$

As has long been noted, this scene is evidently written with the recognition scene of Aeschylus' Libation Bearers in mind, because of its explicit rejection of the tokens used in the Aeschylean version (lock, footprints, garment) and its replacing them with Orestes' scar. If the crucial lines in this respect (El.518-44) are indeed written for theatrical practice and not an interpolation by a scribe for a reading public, this is a prime example of performative cross-referencing in Greek drama (and the best-documented case in surviving tragedy). The scene's most remarkable feature is its very existence in the context of a competitive performance. For it would not have been written and conceived of in this way at all were it not for the presence of audience members who would instantly make the connection with the Aeschylean play and decode the rationalistic critique launched in the Euripidean rejoinder.

Who were these audience members? Presumably the same as those who would commission their drinking utensils for the symposium to be adorned with scenes related to the Oresteia. Indeed, these vase paintings, well documented in the monographs by Prag and Knoepfler, ${ }^{6}$ provide fascinating analogies for audience response in the theatre. As the Electra scene with its subtle allusion to the Aeschylean play constitutes a theatrical challenge to any playgoer's individual competence, so the vase paintings with their lack of name-tags pose iconographic puzzles to the viewer. In the symposium context these vessels create matrices of competition among the symposiasts, excluding anyone who lacks the expertise needed to decode the iconography. Given that the prime occasion for viewing these vessels, the aristocratic symposium, is a celebration of a socially cohesive group of aristocrats (re)affirming their bonds, it is intrinsically likely that most of these symposiasts were indeed capable of decoding the iconographic puzzles before

3 Arist. Politics $1341 \mathrm{lb} 15-18$ and 1342a18-22, cf. Poetics 1453a33-5.

${ }^{4}$ Arist. Politics $1281 \mathrm{~b} 7-10$, see also $1286 \mathrm{a} 30 \mathrm{f}$.
5 The most recent discussions are Seidensticker (1996) 24-6; Davies (1998); and Gallagher (2003), which contain ample references to earlier literature.

6 Prag (1985); Knoepfler (1993). 
them. In other words, these vases would not exist if the predominant response to the iconographies in their primary context of use were (socially exclusive) ignorance and puzzlement rather than (socially inclusive) recognition. ${ }^{7}$

Such a 'top-down' approach, as I would like to call it, to the competence issue has its merits. But the limitations of focusing on high-level competence are equally obvious. Just how far down the social ladder can this sort of inter-textual (or inter-performative) and mythological competence - acquired by a mixture of education, playgoing, symposiastic activity and, presumably, reading - be taken for granted in a case such as the Euripidean recognition scene, notably on the assumption that the Athenian audience is broadly stratified in social terms (a view which will be endorsed in the course of this paper)? And even if, for the sake of argument, the view is adopted that the Athenian audience of the Electra was socially homogeneous and primarily upper-class, would all of the spectators, or even the majority of them, engage with the scene at such a high level? Most of all, does the scene need and pre-suppose this level of shared audience competence at all in order to 'work' and be theatrically effective? Does failure to make the connection with the Aeschylean play actually result in an exclusion similar to that of a viewer who lacks the knowledge needed to solve the iconographic puzzle posed by an Oresteia-related vase painting? It would seem that the analogy between theatre and vase paintings which I have just developed breaks down at precisely this point: the Electra remains intelligible, and continues to appeal, without knowledge of the Aeschylean model, whereas knowledge of the narrative underlying specific iconographies is crucial in order to make sense of them in the first place. If theatrical communication is by its very nature more inclusive and has lower barriers of entry, is it then the case that Euripides, when embarking on this intriguing inter-theatrical discourse with his illustrious predecessor, deliberately generates challenging layers of meaning? And do these layers correspond to various strata of connoisseurship, creating a theatre of what may be branded 'layered inclusion' which manages not to alienate any viewer but thrives even if, to redeploy Aristotle's terminology, the story is 'well-known only to a few', because it 'nevertheless delights all'?

As has become obvious from the Aristotle passage and the recognition scene of the Euripidean Electra, audience competence is a problem of some complexity. One might hope to gain further insights from the rival genre of comedy with its overtness in things (meta)theatrical. What instantly comes to mind in this context are the regular cases of comic playwrights attributing sophistication and discerning taste to their audience. But such utterances are problematic in their own right. In this rhetoric the audience, or more narrowly the judges, are of course refined

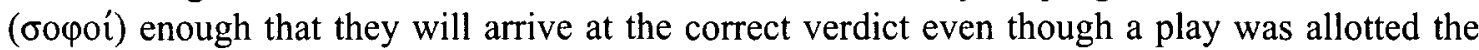
first performance slot in the competition (Assembly Women 1155-62). Cleon will surely be rec-

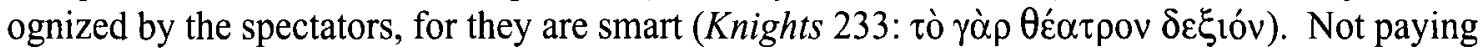
attention to what the chorus has to say is characteristic of a stupid audience, but not the present

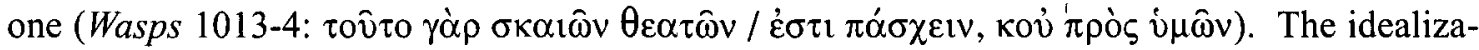
tion might go as far as reducing the audience to one gathering of old and wise men (Plato fr. 96, from Xantai or Kerkopes):

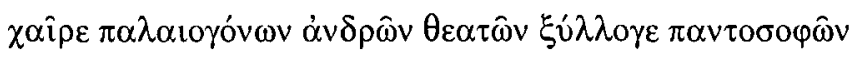

Be greeted, assembly of men born long ago, most sophisticated spectators.

7 These issues are explored further by Revermann (2005) 9-12, not, however, with reference to Attic vase paintings but to the magnificent South Italian 'Cleveland Medea' crater (dated to c. 400). 
Extending the gist of this kind of rhetoric addressed to audiences of comedy to playgoers-at-large might seem legitimate on the reasonable (though in the last resort unprovable) assumption that audiences at competitions for tragedy, satyr-play and dithyramb did not differ significantly from those of comedy. ${ }^{8}$

When assessing utterances of this kind, not only must it be borne in mind that they are driven by communicative agendas which are more than transparent: this is, after all, a competition, and flattery, one would think, always comes in handy. Equally important, though surprising and perhaps even confusing, is the fact that on a number of occasions a comic playwright tells his audience that they (as a collective) are, or were, not competent. Aristophanes' disillusioned comments in the revised parabasis of Clouds on the spectators whom he blames for the play's failure to be awarded first prize in 423 quickly come to mind (the statement is without doubt employed to instil in the prospective audience a sense of obligation to get it right the second time round). Other instances are perhaps even more telling. When Cratinus, in a parabatic remark of an unknown play, accuses his audience of untimely laughter, he seems to highlight a major faux pas of any playgoer: a reaction which is desired by the playwright and sanctioned by theatrical convention (in this case laughter), but which comes at the wrong cue, the ultimate give-away of the eager yet dull spectator. This remark, however, is embedded in conciliatory rhetoric which distinguishes between the actual performance and the process of adjudication in its aftermath, hence giving the insult to the audience a strong ironic tinge (Cratinus $f r$. 360, unknown play):

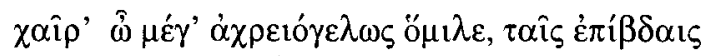

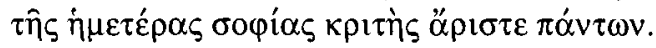

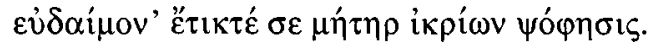

Be greeted, crowd, laughing loudly at the wrong time but in the aftermath our craft's best judge of all. Your mother, the noise of the benches, bore you as a happy child.

At the other end of the scale, hyper-sophistication can be a problem (Cratinus $f r$. 342, play unknown):

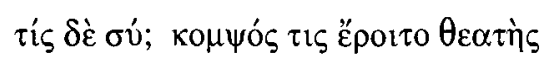

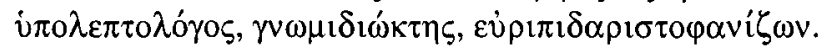

'Who are you?', some smartass-spectator might ask, over-subtle when it comes to speech, eager to pick up little statements, a Euripidaristophanizer.9

Audience vilification - this strong word is apposite - is a phenomenon which would not necessarily be expected in a competitive environment: how can playwrights afford to take such a liberty as to blame or even insult the audience without risking unfavourable reactions which are bound to have some impact on their success? The iambographic roots of the genre must be pertinent here. ${ }^{10}$ Most of all, however, redirecting comedy's penchant for personal invective (óvo$\mu \alpha \sigma \tau i \mathrm{i} \omega \mu \omega \delta \varepsilon \hat{i} v)$ towards its viewers is, ultimately, deployed by playwrights as something they hope to gain from, some sort of an asset: it is meant to be funny, some source of amusement for the audience thus insulted. At any rate, it is evident that comic passages attributing or denying expertise to the audience are delicate evidence, to say the least, to bring to bear on the compe-

\footnotetext{
8 Part of the problem is uncertainty as to the exact sequence of plays at the Athenian festivals; see Csapo and Slater (1995) 107 and 123-4.

${ }^{9}$ I follow Ruffell (2002) 160 in not assuming a full stop after $\theta \varepsilon \alpha \tau$ ís (also preferred by Storey and Allan (2005) 141), contra Kassel-Austin, Kock and Meineke.
}

That, as is often argued, Aristophanes himself should be called an 'Euripidaristophanizer' does not quite make sense, and is not necessarily implied by the scholiast quoting the passage.

10 Rosen (1988); Bowie (2002). 
tence question. They shed some light on manipulative strategies which underlie the rapport that playwrights try to establish with their audience. But perhaps the most interesting aspect surrounding the rhetoric of audience praise and vilification is its very existence: audience competence is a matter of concern to playwrights, a part of the theatrical experience which is subject to reflection, exploration and challenge.

A more promising approach to competence, and one that will lead me to the novel strategy adopted in this article, is via paratragedy. This is a theatrically rich and complex phenomenon which operates not just on the plain linguistic level of the spoken word, but also involves paralinguistic and visual signs (rhythm, gesture, costume, as well as, it would seem, pitch and intonation). In addition, instances of paratragedy may involve music, which introduces new layers on top of an already complex set of parameters: melody, rhythm (again), colour of tone, pitch (again, including falsetto), phrasing, volume, even another agent and generator of signs, the aulos-player (who on occasion may have been integrated into the action"1). Moreover, paratragedy is often a somewhat organic and evolving theatrical process, the prime objective of which is to create an 'atmosphere', 'environment' or 'mood' reminiscent of tragedy, and which rests on levels of familiarity with tragic plots, plot-patterns or even little plot-pieces. ${ }^{12}$ Appeal to these patterns can be fairly straightforward or more complex. Suffice it to point to Dicaeopolis' 'chopping-block speech' in Acharnians, where a single prop and the action associated with it materialize, displace, focalize, distort, signal, evoke and condense a tragic mini-pattern.

Appreciating this performative complexity of paratragedy is crucial for addressing the problem of audience competence. Paratragedy is of course an important, albeit not the sole, indicator of competence. But decoding paratragedy is at least as multi-layered as the processes creating it. Paratragedy implies, in other words, different levels of understanding, and the notion of stratification is bound to be a vital part of any viable solution to the competence issue. In performance the presence of paratragedy is usually not at all difficult to spot, while at the same time it normally invites, even demands, the audience to respond at various levels of sophistication. This, it may be argued, is in fact a prime function of paratragedy: to unite the audience in their general ability to spot a paratragic 'environment', 'atmosphere' or 'mood', and simultaneously to differentiate between members of the audience according to their levels of appreciation. Paratragedy, then, performs the double act of being appealing to all - a sine qua non for success at the competitive dramatic festivals - while inviting layered responses and creating strata of connoisseurship. The ideology and communicative strategies underlying the use of paratragedy are not dissimilar to what a friend described to me as the impact of seeing Tom Stoppard's Arcadia: 'Everyone walks out of the theatre and feels smart.' Note that in the intriguing passage of Aristotle quoted above similar dynamics of integration in conjunction with differentiation are

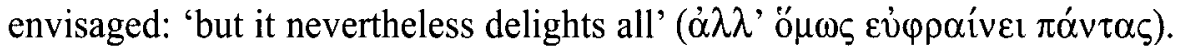

Paratragedy is important to my project not just because it is a vital aspect of the competence problem, but because it illustrates the kind of strategy with which it has to be (re)approached. To put the matter bluntly, the competence issue must be framed not (inter)textually but theatrically, with philological rigour but also with due regard for the theatrical event as a whole and the ways in which audiences construe meaning in theatrical communication. I will therefore address the problem by starting not with the plays but with the people who watched them, not from the angle of production but of cultural consumption, and with a primary interest not in the high but in the low end of expertise. The novelty, then, of the method adopted in this article is that, instead of going 'top-down', I will pursue a 'bottom-up' strategy which is centred around the consumer of $60-1$

11 Taplin (1993) 70-5 and appendix II; Wilson (2002)

12 Points well made by Silk (1993) and (2000) 351-6, which usefully complement the classic, if conceptually narrow, discussion of paratragedy by Rau (1967). See also Revermann (2006) 155-6 and 232-5. 
the cultural commodity 'theatre' and the complex bundle of skill-sets activitated during the process of playgoing. Is it possible to identify some bottom line of expertise? Can we qualify, and perhaps even attempt to quantify, a common denominator, a certain standard of competence which was shared not by a few but by the great majority of the viewers and evaluators of classical drama? And once the bottom line of competence is established, which patterns of stratification might be discernible?

My problem-solving strategy involves three steps. To begin with, the very concept of 'competence' needs to be addressed, in particular whether using it in the plural and distinguishing among various types of competence might open up promising paths of exploration. 'Theatrical competence' as an umbrella-notion for a multitude of sub-competences will emerge as my key concept when trying to define a bottom line of expertise. In a second step, I wish to bring to bear on the question of competence two important characteristics that are peculiar to Athenian drama of the fifth and fourth centuries and which set it apart from all Western and non-Western theatrical traditions of similar calibre. First, the fact that at the grandest and most important competitive dramatic festival, the Great Dionysia, all choruses (for drama and dithyramb) had to be composed of Athenian citizens. Is there any chance of quantifying this participation of the citizen body with some degree of plausibility? And what effects does this sort of inter-penetration of audience and actors have on spectatorship? I then intend to capitalize on the fact that the plays were performed in an annual competitive festive context which invited frequent exposure to a type of drama that shows a remarkable formal conservatism. What are the implications of regular exposure to an intrinsically conservative art form for audience competence? In the final part, the argument will be fleshed out by being applied to the plays themselves. The focus will be on select instances of complex theatricality: paratragedy in Thesmophoriazusae, the existence of parabatic inter-textuality in comedy and a notorious passage in Frogs. What will be argued for in these case studies is a model of stratified competence and decoding which allows for a whole spectrum of responses to the complex pieces that were put before diverse audiences composed of élite and non-élite members. In the contexts of competitive performance the plays are designed, and have to be designed, to appeal to all segments of those broadly stratified audiences by whom they were evaluated.

Restrictions of scope are mandatory with a topic as large and complex as the present one. First, my focus throughout will be on the audiences of fifth- and fourth-century Athens and Attica, on two grounds. In Athens, for one thing, we find as well developed a song-culture as anywhere, in which individuals are constantly exposed to and participate in choruses and sung rituals of various descriptions. ${ }^{13}$ Yet Athens appears to be a somewhat special case in ways crucial to the topic of this article. Kowalzig stresses the exceptional nature of the Athenian choral world, which lacked, as far we know, institutionalized women's dancing and where there were 'few khoroi other than those for Dionysos'. She goes so far as to attribute to drama a 'choral monopoly', and while this may be overstated, noting the central rôle of dramatic chorality in Athenian song-culture is a valid point. ${ }^{14}$

Secondly, of all spectators who have been exposed to classical drama up to the present day, those in Athens are surely the most important ones. Increasingly living up to rhetoric describing her as the cultural capital of Greece, Athens, her judges and the verdict of her audiences were formative. Most, probably all, of the fully preserved tragedies and comedies were being performed in Athens at some point in their stage lives, usually at the beginning. This pre-eminence is reflected in the comparative wealth of information we have about the dramatic competitions in Athens and Attica as opposed to the (very) little that is known of dramatic festivals elsewhere.

13 On Athens (and other cities) as a song-culture, see West (1992) ch.1, esp. 16-17; Wilson (2000a) passim; Herington (1985) passim. 
The Athenocentric picture which thus emerges is without doubt skewed and misleading although it correctly mirrors the place of Athens as the centre of gravity for drama (among other things). But the ever-increasing dissemination of drama during the fifth and fourth centuries - as demonstrated by the spread of theatre-related iconography, dramatic texts, theatre buildings, dramatic festivals and the choregic system - strongly suggests that similar kinds and degrees of competence can safely be assumed for much of the Greek cultural continuum. ${ }^{15}$

Thirdly, as has been apparent already and will be even more so in the final section (IV), when exploring how in theatrical practice playwrights appeal to various kinds and layers of audience competence this article will concentrate on comedy, on the grounds that this genre, given its persistent metatheatrical bias and cross-generic outreach, throws the phenomena at stake into sharpest relief. Everything that will be subsumed under the umbrella-notion of 'theatrical competence' - notably a sense of genre and genre-specific theatricality as well as the ability to spot inter-textual points of reference (dramatic and non-dramatic) - can be demonstrated most clearly for comedy while constantly being activated in similar ways by the viewer of tragedy and satyr-play. The insights gained from examining comedy are therefore applicable to the whole of preserved Greek drama, (again) bearing in mind the plausible assumption that audiences of comedy and tragedy did not differ substantially.

\section{COMPETENCE AND THE POWER OF DEFINITION}

If the theatrical event can be described as a complex exchange of signs between actors and audience, competence in theatrical communication is the ability to decode and encode those signs. ${ }^{16}$ This very broad semiotic definition considers actors and audience as both generators and recipients of signs. Within this scheme of things, acting itself or picking up non-verbal responses from the audience are competences as much as the spectators' ability to engage with the performance, or their familiarity with sanctioned patterns of behaviour (when to applaud and when not during a performance of classical Western music, for instance).

Competence, then, is a skill-set which is both innate and, to a significant extent, acquired on the basis of an individual's cognitive and emotional pre-disposition as well as socialization. These skill-sets are culturally conditioned, actualized on demand and evolve according to experience, memory and practice. Competences may be dormant or peter out owing to prolonged non-activation. It is vital to give due credit to the sociological and habitual dimension of competence-acquisition when assessing the leverages that make for divergent levels of expertise: sheer quantity of exposure and the continued need to activate skill-sets may, for instance, be far more instrumental to developing and sustaining competence than an individual's cognitive and intellectual predisposition.

A second general observation to make is that the area for differentiation between greater and lesser competence may be comparatively small. Theatre is an excellent example: virtually everyone is capable of decoding theatrical communication of any kind - at least to some extent - simply by being human, principally because of the paramount importance of the visual and the absence of a literacy-based barrier to access. A performance of The Cherry Orchard in Russian will not be entirely lost even on a spectator who is ignorant of both Russian and the Chekhov script. Most Westerners will leave a performance of Japanese kabuki or Beijing opera with bewilderment but also a sense of having understood something about the basics of the plots or certain characters in it (even if spectators may be totally at sea as to whether what they think they

\footnotetext{
15 On the dissemination of drama beyond Athens and Attica, see Easterling (1994); Csapo and Slater (1995) 117; Dearden (1999); Taplin (1999) 34-43; Revermann (1999/2000); Wilson (2000a) 265-302; Csapo (2004b).
}

16 de Marinis (1993) 171-7; Elam (2002) 88-9 and 124-5. On the related concept of literary competence, see Culler (1975) 113-30. 
understood is remotely similar to what an experienced 'native viewer' grasps). All of this is a far cry from, say, the ability to read a Chinese novel. Making sense of theatre is, at least on a basic level, an easy competence to acquire in comparison with other cultural skills, especially those commonly associated with 'literary' or 'high culture' in the broadest sense. One sociological consequence of this is readily apparent: the smaller the bandwidth for differentiation of proficiency, the more contested this differentiation becomes. I will return to this point shortly.

What makes theatrical communication so fascinating is its sheer complexity. Hence I use 'theatrical competence' as a correspondingly loose umbrella-notion which encompasses a multitude of (sub) skill-sets, be they of a linguistic, visual, behavioural, inter-textual (or rather intertheatrical), cognitive or broadly cultural nature. While all of these sub-competences are commonly invoked simultaneously during a performance, some may become dominant at any time (corresponding to certain types of codes becoming temporarily or permanently dominant in the actual performance). For instance, during those moments immediately after a modern Western play has ended, behavioural competence about how to applaud (seated, with the possibility of a standing ovation as the highest mark of respect) suddenly becomes dominant. Spotting 'the end' itself is a spectator's task (facilitated or not by the use of a curtain), as may be identifying those moments in the ongoing performance where applause or vocal intervention (calls of 'bravo') are socially sanctioned. Moreover, the importance of individual (sub)competences may vary significantly from one theatrical culture to another. Japanese kabuki makes heavy demands on an audience's ability to decode colour symbolism, whereas two areas with which Greek theatre presupposes a high degree of familiarity are chorality and music (both for good reasons, as will soon become clearer).

My emphasis on the complexity of theatrical communication may strike the attentive reader as being at odds with my earlier claim about the comparative accessibility of theatre. In fact, the two claims are at odds with each other. They constitute the key paradox of theatrical communication: the fact that theatre is both complex and accessible, difficult and easy at the same time. Any attempt to tackle the competence problem has to take this paradox into account. It must do so by working with the notion of stratification and by trying to specify the lines along which stratifications of expertise manifest themselves.

So far my discussion of competence as a methodological concept has been predominantly formal and semiotic. In the practice of theatrical or theatre-related discourse things become messier, and more interesting. Here the definition of who is a competent playgoer and who is not is a means of articulating social differentiation and cultural (or, more narrowly, artistic) selfdefinition. The rhetoric of the anti-theatrical tradition across the ages - more precisely those voices which concede at least some value to theatre, even if by way of purging or straightforward censorship - would be pertinent here (and vastly beyond the scope of this article). ${ }^{17}$ But Aristotle, who can definitely not be regarded as anti-theatrical, is an even more fascinating case in point. For Aristotle the scientist and moral philosopher, 'viewing' - both in the sense of perception $(\alpha i \sigma \theta \eta \sigma i \varsigma)$ and intellectual inquiry $(\theta \varepsilon \omega p i \alpha)$ - is something profoundly positive on the grounds that it is the prerequisite for knowledge-acquisition, even happiness ( $\varepsilon \dot{\delta} \delta \alpha \mu o v i \alpha)$. For Aristotle the analyst of theatre, however, 'viewing' famously becomes a mixed blessing at best. Aristotle's position on 'viewing' (ö $\psi 1 \varsigma$ this time) in the Poetics is neither entirely clear nor consistent. ${ }^{18}$ But whichever way the evidence is approached there can be no doubt that for Aristotle the visual dimension is not at the centre of tragedy's power, appeal and greatness. I believe that scholars have not been sufficiently startled by the apparent shifts of ideology here, and submit that these shifts are at least in part motivated by (not necessarily conscious) strategies of social

17 Barish (1981) continues to be the standard survey. Solomon (2002) explores the connection between antitheatrical rhetoric and homophobe self-definition.
18 Taplin (1977) 477-9; Halliwell (1998) 337-43; Scott (1999). 


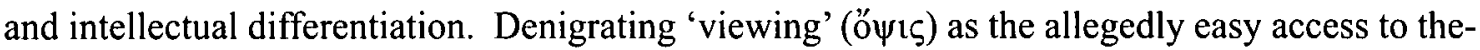
atre in order to highlight other, conceivably more sophisticated skill-sets (some of which may involve literacy or at least be significantly enhanced by continued education and exposure to high culture) serves as a vehicle for making the medium of mass entertainment in Greek culture amenable to layers of connoisseurship which reiterate social and educational differences of society-at-large. In other words, once the mass-commodity 'theatre' is dissected to allow for different levels of cultural consumption, it becomes a subject worthy of being appreciated by 'the few', to deploy Aristotle's terminology. In this model the visual dimension must become the most dispensable because it is shared by most and, on a superficial level, allows for least differentiation. What is remarkable, in other words, are the cultural politics which underlie Aristotle's low esteem of 'viewing'. Its denigration is part of an attempt to redefine a cultural commodity so that it becomes, or rather remains, suitable for aristocratic perusal at a time when its very exclusivity is increasingly challenged by mass consumption in large venues featuring highly mobile theatre practitioners who perform in front of big and diverse audiences (see also p. 114 below).

\section{DRAWING THE BOTTOM LINE}

With the umbrella-notion of 'theatrical competence' thus established, the problem of drawing the bottom line can be addressed. I wish to deploy two strategies. One is to try to measure, in quantitative and qualitative terms, the degree of active participation with which non-actors were involved as choreutai in the theatrical events of fifth- and fourth-century Athens. The other consists in assessing the effects on spectators of continuous exposure to an art form as conservative (in formal terms) as Athenian drama, in a cultural environment which called for, and trained, skill-sets not dissimilar to those needed for theatrical competence in the contexts of ritual, the symposium and military training.

It would seem almost a breach of protocol not to start tackling the issue by pointing to the Greek 'choral culture' which in the Archaic and Classical periods manifestly pervades both edu-

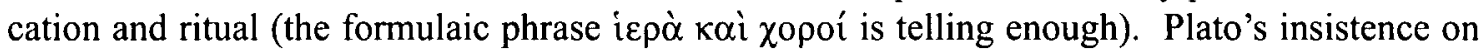
the importance of chorality, which culminates in his calling that person uneducated ( $\dot{\alpha} \pi \alpha i \delta \varepsilon v-$ $\tau \circ \varsigma)$ who has not been trained in a chorus ( $\dot{\chi} \chi 0$ $\rho \varepsilon v \tau o \varsigma)$, is de rigueur in this context. ${ }^{19}$ Things become more engaging once the focus is on Athens in general and its choruses in particular. By comparison, Athenian chorality emerges as interestingly peculiar, with drama and dithyramb being the dominant (and some even argue exclusive) fields for choral activity. Simplifying matters for the time being, choruses in Athens are masculine in composition (with an age-stratification that includes adolescents), Dionysiac in ritual orientation and democratic in ideology of recruitment. ${ }^{20}$

It is especially the last of these features which provides some leverage for the competence issue. At the Great Dionysia, only citizens were eligible to perform as choreutai, whether in dithyrambs (where recruitment was by membership in a tribe) or in drama (where recruitment was not tribal). Infringements are documented, together with mechanisms for dealing with them. These are informed both by the notion of competitive fairness and the ideology of 'civic purity' (to use Wilson's term). ${ }^{21}$ Regulating access and eligibility are acts of power, and it is evident how the ideology of the citizen body inscribes itself into chorality. This social practice is traditional and revolutionary at the same time, an act of both continuity and innovation: as with Greek choruses of the Archaic period, it is those in power who dance in a chorus - only that the pool of eligibility in the fifth century shifted significantly, now including 'the many' (oi $\pi \circ \lambda \lambda o^{\prime}$ ) instead of being narrowed down to 'the few' (oi ó $\lambda \hat{i}$ 'ol). Democratization of chorality in prin-

19 Plato, Laws 654a9-bl.

21 Wilson (2000a) 80-1.

${ }^{20}$ Kowalzig (2004) 39-44 and 60-5. 
ciple, however, need not mean broad social stratification of choreutai in practice. Who, then, danced in the Theatre of Dionysus?

There is a quantitative answer to this question. In Athens the annual demand for male choreutai was high, by any standard:

\author{
DithYRAMB \\ 20 choruses ( 10 of adults, 10 of boys) of 50 choreutai each \\ $=1000$ \\ TRAGEDY AND SATYR-PLAY22 \\ 3 choruses of 12 or (since Sophocles) 15 choreutai \\ $=36$ or 45 \\ COMEDY \\ 5 (3 during the Peloponnesian War?23) choruses of 24 choreutai \\ $=120(72 ?)$
}

Total: a minimum of 1,117 and a maximum of 1,165 (of adult male citizens: 617 or 665)

Impressive as these figures are by themselves, they only come to life when contextualized within the thorny field of Athenian demographics. Experts here essentially argue whether the maximum number of male adult Athenian citizens in the fourth century, for which documentation is best, was in the region of $20,000+$ or $30,000+.24$ If the higher of these estimates is adopted, and on the assumption of, say, 35,000 adult males eligible for the $c .600$ slots for dramatic choruses and adult dithyrambic choruses, this yields slightly less than $2 \%$ of the male adult population as the lowest level of practical involvement in the contests each year. For the period of the Peloponnesian War, and that is for the period in which more than half of our 44 preserved classical dramas were performed, the number of eligible males will have been significantly lower owing to casualties and war-related absences. In a year like 411, the date of Lysistrata and Thesmophoriazusae - that is, in the middle of the war, after the Plague and the Sicilian Expedition - the figures may have been as low as 25,000 or, on the lower general estimate, even 15,000 . In the latter case, this would mean that at the Great Dionysia $4 \%$ of the adult male citizen population were performing in the orchestra at some point of the festival. Each and every year then, even in war years, the Athenian polis does, and apparently can, rely on recruiting between $2 \%$ and $4 \%$ of its male adult citizen population for performances of drama or dithyramb at the Great Dionysia, and it polices infringements of the citizenship prerequisite. It is against the backdrop of such a choral culture that Plutarch's anecdote about Athenian prisoners

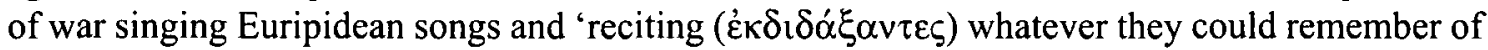
his poetry' makes perfect sense (as does the fact that their captors were so impressed that they released the prisoners: Euripides is, after all, a shared cultural commodity). ${ }^{25}$

\footnotetext{
22 I assume that the same choreutai perform throughout a whole tetralogy. This view commends itself on the practical grounds of recruitment, training and fairness of resource-allocation (which we know from the assignment of actors to choregoi to have been a prime concern in the competitive festival-environment). Green (1994) $10 \mathrm{n} .23$, however, believes that there was no such continuity, in particular for satyr-plays where, he argues, the choreutai 'needed to be fresh and vigorous'. If this were true, the annual demand for trained choreutai would be even higher. Another assumption of mine is that Aristotle's remark (Politics 1276b1-9) that tragic and comic choruses could be composed of the same men is, if anything, the exception and not the rule. Theoretically speaking, in the
}

absolutely minimalist scenario (which is that all tragic choreutai (15 in each chorus) also perform in (only) three comic choruses made up of 24 choreutai each) $45+(3 \times 9)$ $=72$ men are needed for all dramatic choruses.

${ }^{23}$ On the controversy over the number of comedies during the Peloponnesian War, see Luppe (1972) and (2000) as well as Storey (2002).

${ }^{24}$ See Hansen (1986) and Scheidel in Garnsey (1998) 197-8, who provides a synopsis of the scholarly literature. Also note Scheidel (forthcoming).

25 Plut. Nicias 29.3. On Euripides as a cultural icon from the late fifth century onwards, see Revermann (1999/2000) and Roselli (2005). 
These figures are conservative ones, for age is likely to have been a major recruitment criterion, thus further narrowing the pool of eligible males. While Winkler's thesis that being a choreutes was part of the Athenian ephebic service is generally rejected, ${ }^{26}$ it is highly plausible that the sheer physicality of the task would, as a rule of thumb, call for dancers who were comparatively young, especially in dramatic choruses. According to Plato, a dancer in a chorus of Dionysus is ideally under thirty (Laws 665b3-6). Demosthenes (Against Meidias 60) mentions

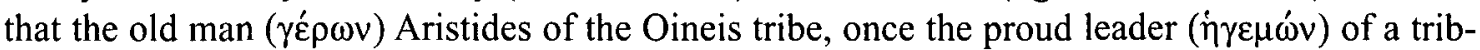

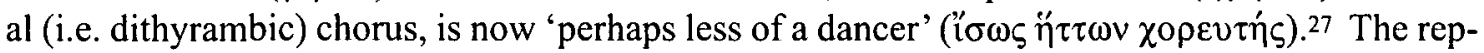
resentation of choreutai as young and beardless on the Pronomos vase that gave rise to Winkler's thesis would, then, be idealizing in depicting the dancers as adolescents. But it may well be indicative of a bias towards recruiting choreutai while they were still in their physical prime.

Part of the mechanism which helped ensure that choral supply could meet demand is evident from the system itself: it is surely no mistake to regard the ten dithyrambic boy-choruses as some sort of boot-camp. A set-up which insisted on each tribe recruiting from the demographically small stratum of male adolescents the same number of choreutai that was needed to staff the adult dithyrambic choruses has the notion of intelligent human-resource management and development written all over it. Dramatic choruses were no doubt different. While the absence of tribal recruitment implies that the citizen body was less blatantly inscribed into the texture of dramatic chorality, the more flexible recruitment criteria gave due credit to the higher demands made in drama on choreutai (movement and gesture, costume, singing while wearing a mask, ensemble-playing, highly varied music and choreography). Because of its smaller size and higher complexity, amateurism is more readily apparent in drama than dithyramb. ${ }^{28}$

So much for numbers. But is there also a qualitative, or rather sociological, answer to the question of 'Who danced in the Theatre of Dionysus?' Egalitarian and democratic as the ideology of the citizen-chorus may be, this need not, of course, translate materially into broad social stratification at all. The problem is not made any easier by the fact that, as so often when it comes to matters sociological, the interest of our élite literary sources in things to do with class is either non-existent or blatantly polemical.

A recent (and excellent) discussion of the sociology of dramatic and dithyrambic choreutai utilizes both literary sources and features of the choregic system as a social practice to arrive at a solution. ${ }^{29}$ Wilson develops two scenarios in his important monograph, in the sections on recruitment and choregic patronage respectively. ${ }^{30}$ When framing the issue from the recruitment angle, the choreutai for drama and dithyramb are members of the wealthy élite (75): '...khoreutai were in general drawn from a not dissimilar social and economic background as khoregoi'. Two arguments are brought to bear here: the highly personal nature of the recruitment process which required a good network, and the rôle which the boys' dithyramb played in the education of those whose families traditionally valued choral dancing and who could afford sustained periods of their boys' absence. A different picture, however, emerges once the issue is seen from the perspective of choregic patronage. Now the fact that choreutai receive pay becomes relevant, making dramatic and dithyrambic chorality in Athens a system of exchange and patronage (128): 'a substantial percentage of the citizen body was thus effectively under the

26 Winkler (1990) with the discussion in Wilson (2000a) 77-9.

27 On this passage, see also MacDowell (1990) 281.

28 Amateurism is attested: without specifying the kind of chorus, Menander fr. 130 (from Epikleros) mentions as regular practice that two or three choreutai simply fill the ranks but do not sing, standing furthest away from the audience; see Gould and Lewis (1988) 241-2.
${ }^{29}$ On the social background of poets and performers, see also Griffith (1995) $68 \mathrm{n} .21$ and $73 \mathrm{n} .48$, as well as Wilson (2002) 49 and 52-4.

30 Wilson (2000a) 75-80 and 123-30 respectively. Also note Pritchard (2000) and (2004), who argues for an élite background of the boys and men participating in dithyrambic choruses. 
pay of private individuals [Wilson's italics] in this way for several months every year', which leads to the 'minimal conclusion ... that khoreutai were in general likely to be of lower economic standing than their khoregoi'.

Our source for this, the 'Old Oligarch' (1.13), though heavily biased and blatantly polemical, is too weighty to be dismissed, ${ }^{31}$ and too interesting not to be quoted (yet again) in full (the text is that of Marchant's OCT edition):

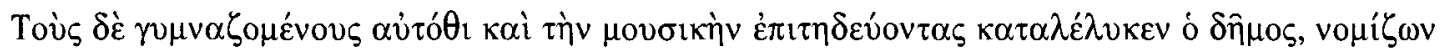

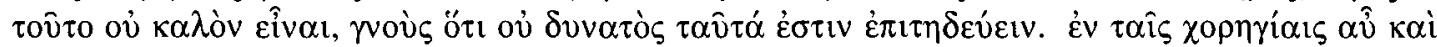

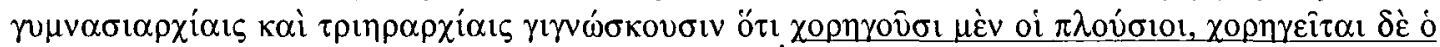

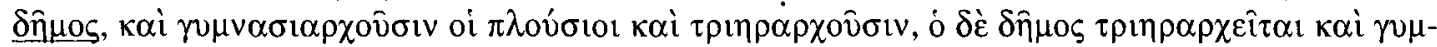

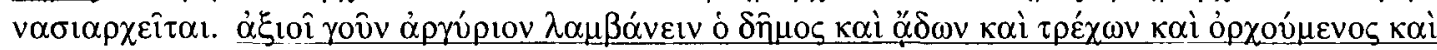

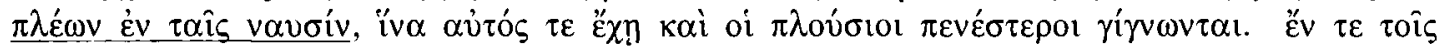

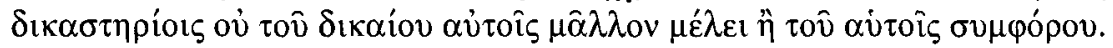

Those who pursue physical exercise and culture have been disbanded by the demos which believes that these activities are undesirable, being fully aware that it is not capable of pursuing them. As far as the funding of choruses, the sponsoring of athletic competitions and the provision of triremes are concerned, they realize that the rich provide the funding of choruses while the demos is at the receiving end, and that the rich sponsor the contests and provide the triremes while the demos serves in triremes and is sponsored at contests. For the demos is keen on receiving money for singing, running, dancing and sailing in the fleet, so that the demos has money while the rich become poorer. And in courts they are not concerned with what is just rather than with their own advantage.

Fairness of discussion is evidently not the order of the day here, and the polar opposition between the wealthy and the demos is correspondingly crude and undifferentiated. But that choreutai in drama and/or dithyramb could come from the lowest class of citizens (thetes) is presupposed for the polemics of the passage to make sense in the first place. ${ }^{32}$

As always when two seemingly opposite views can each be proposed with some degree of plausibility, it is worth entertaining the thought that both may, in a sense, be true. The statistics alone, as set out above, make a purely aristocratic recruitment system unlikely to begin with (even if, as Pritchard insists, there is in principle enough manpower among the wealthy élite to staff the dithyrambic choruses with exclusively upper-class choreutai). ${ }^{33}$ And with drama becoming bigger and bigger business in the course of the fifth century and beyond, a concomitantly larger appeal should result in a broader recruitment basis than existed at the beginning of the fifth century.

In addition, I wonder whether hints can be derived from an important choral passage at the beginning of the parabatic anapaests of Aristophanes' Knights (507-11):

31 Its authority is, however, called into question by Pritchard (2004) 215, who instead concludes on the basis of Antiphon 6.13 that the choregos provided not pay

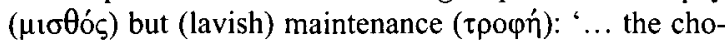
rus sponsor, instead of wages, provided for the daily needs of khoreutai by organizing the necessary purchases himself and paying for them out of his own pocket' (on the Antiphon passage, see also Wilson (2000a) 82 and 124).

32 Also note that in Politics 8.1342a18-22 Aristotle distinguishes between two types of spectators, the educated one ( $\left.\dot{\varepsilon} \lambda \varepsilon v \dot{\theta} \theta \varepsilon \rho \circ \varsigma \kappa \alpha i \mathrm{i} \pi \varepsilon \pi \alpha 1 \delta \varepsilon v \mu \varepsilon \varepsilon^{\prime} \nu \varsigma\right)$ and the vul- gar one, which explicitly includes the lowest class of cit-

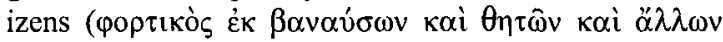

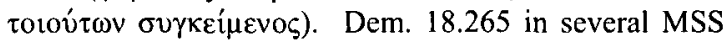
contains a phrase which implies that participating in a chorus was a lower-class affair (as opposed to being a

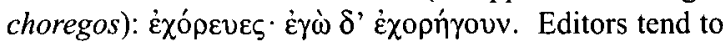
view it as an interpolation (Wankel (1976) 1162; Yunis (2001) 258; but see Wilson (2000a) 352 n.65). Yet even as an interpolation it is interesting, if much less valuable, evidence.

33 Pritchard (2004). 


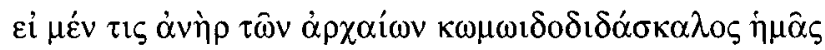

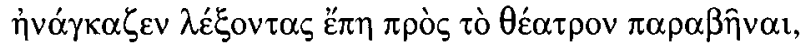

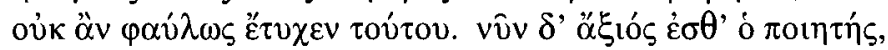

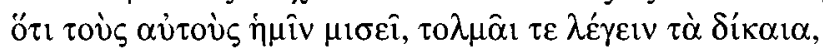

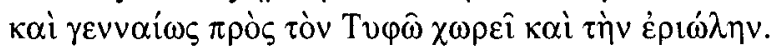

If one of the old playwrights had forced us to step forward and speak to the theatre, he would not have achieved this easily. Now, however, the poet is worthy, for he hates the same people we do, dares speak what is just, and nobly advances against the typhoon and the whirlwind.

The point cannot be pressed, but on the assumption that the choral persona of knights is still lingering here, the passage suggests that in 424 being an Athenian knight and performing in a comic chorus do 'not easily' (oủ $\varphi \alpha v$ $\lambda \omega \varsigma$ ) go together, even if the existence of some means of coercion is similarly implied. ${ }^{34}$ A link between class, chorality and genre along such lines would seem plausible, as tragedy must have had a distinct appeal to aristocrats. Against the backdrop that tragic choruses, as opposed to their comic counterparts, would regularly be staffed by members of the upper class, the passage takes on the sort of colouring one would expect from Aristophanic rhetoric, which is suspiciously eager to dispel any notion of inferiority, not just to rival comic playwrights but, notably, to tragedy: it takes, of course, a playwright of Aristophanes' calibre to recruit choreutai of a social standing which would, under normal circumstances, make participation in a comic chorus the less desirable option. ${ }^{35}$

If, as I am inclined to assume, dramatic chorality was broadly stratified in such a manner, this would have interesting implications. Not only should the same apply to at least the adult dithyrambic choruses, if only because of their sheer size, but most of all, the contested issue of audience composition would be affected. ${ }^{36}$ For if all classes of Athenian citizens regularly participated in dramatic choruses, the case for assuming similarly stratified audiences would be strengthened a fortiori, since the selection of those who performed is bound to have had an impact on those who watched and vice versa. While I gravitate towards this view, I hasten to add that the crucial point for the competence issue is not social composition but the very fact of participation as a member of an amateur citizen-chorus. If, as seems fair to assume, those who watched also performed and the other way round, this interface has significant effects on competence-acquisition as spectator and performer, regardless of an individual's social standing.

To sum up: Athenian choral culture had significant demands for human resources built into it. The annual requirement amounted to $c$. 1100 citizen-performers for dramatic and dithyrambic choruses at the Great Dionysia. There is good reason to believe that in democratic Athens, as elsewhere, those who danced were those in power. They came, in other words, from all the socio-economic strata which constituted the demos. That said, class-based recruitment patterns may have been operative until the 420 s at least, with tragic chorality maintaining a special appeal to the upper class. These choreutai are likely to have been performing in front of audiences who were at least as diverse as they were themselves. At the Great Dionysia this would mean translocal audiences who were diverse in terms of age, social status, places of origin and, perhaps, gender. ${ }^{37}$ The interface between those who performed and those who watched must have been

\footnotetext{
34 On recruiting difficulties and known measures to counter them, see Wilson (2000a) 83.

35 Note in this context that in the Laws (816d3817 al) Plato envisages that, while comedy is essential for everyone in order to understand the serious, comic representation is the preserve of slaves and paid foreigners

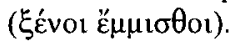

36 The best discussions of this important topic are Sommerstein (1997) 64-72 and (1998), as well as Bowie
}

(1998) 58-60. Both, by contrast with the argument made here, endorse an élite fifth-century audience.

${ }^{37} \mathrm{On}$ the notorious issue of the presence or absence of women, see most succinctly Gould and Lewis (1988) 263-5 and Csapo and Slater (1995) 286-7. Fuller discussions are (in favour of their presence) Dover (1972) 1617; Podlecki (1990); Henderson (1991); SourvinouInwood (2003) 177-84); against their presence: Goldhill (1994); MacDowell (1995) 14-15. Lévy (1976) 104 
considerable. Regardless of whether traditional estimates of the seating capacity of the theatre of Dionysus have to be revised from $c .15,000$ to $c .7000$ or even less, ${ }^{38}$ the percentage of those Athenian spectators at the Great Dionysia who had, at one point or another in their lives, been performing in that very orchestra themselves as members of a dramatic or, more likely, dithyrambic chorus must have been considerable. Therefore, as much as the spectators may have differed in terms of their educational and social background, a substantial portion of them would be united through the theatrical experience of having performed in the theatre of Dionysus themselves. Many metics and foreigners will have acquired similar choral expertise in different contexts. It is crucial to draw attention at this point to the other opportunities for watching and performing that existed not just in the city (the Lenaean festival and, for dithyramb, the Thargelia) but most notably, at the many deme-festivals which would include dramatic competitions. ${ }^{39}$ This phenomenon is all the more important for questions of competence because participation in choruses at deme-festivals is likely to have been restricted to members of the deme. ${ }^{40}$ The central rôle of chorality in Attic drama is not solely a conceptual one but a significant part of the lives of those who would watch and perform both in Athens and throughout Attica. ${ }^{41}$

There is reason to place so much emphasis on this one specific type of theatrical experience: it makes a difference. As anyone who has ever acted himself or herself will confirm, this experience fundamentally shapes how theatre is viewed, perceived and, eventually, evaluated as a spectator. What this means in the ancient theatre can be described more precisely. Performing in the orchestra provides a feel for the dimensions of the spectators' area and the enormous distances in the acting area; for the dynamics of actor-audience interaction and the difficulties of winning and sustaining the interest of large audiences. Naturally, dithyramb and drama provide significantly different levels of theatrical competence. A performer of dithyramb does not experience the difficulties of singing and moving while wearing a mask, even though certain mimetic skills akin to those used in drama may have featured occasionally in dithyramb. ${ }^{42}$ Nor are there any props which have to be moved around and presented to the audience. Nevertheless, performing dithyramb or drama requires a series of other important theatrical skills: group dance in the huge orchestra, co-ordinated sung delivery of proverbially difficult texts, ${ }^{43}$ an awareness and some understanding of structural patterns which the chorus are involved in either as a whole or through their leader (antistrophic or triadic structures in dithyramb and tragedy, epirrhematic structures in comedy); and a familiarity with the tonality and harmonic structures of the music prevalent in both dithyramb and drama.

This is a considerable degree of theatrical competence, shared by a significant portion of the audience members at any competition. It has implications for the playwright and everyone involved in the performance. The more competent audiences are, the more demanding they tend to be, particularly with regard to those areas in which they share a certain amount of expertise. It does not come as a surprise, then, to hear of ancient audiences heavily penalizing mistakes of a sort which a contemporary Western audience may be benign enough to disregard as technical blunders. Hegelochus, to quote a blatant example, acquired remarkable notoriety in comedy by

regards Lys. 1050-1 as an audience address directed at women playgoers, but see Henderson (1987) 191.

38 Dawson (1997); Goette in Csapo (forthcoming).

39 Csapo and Slater (1995) 121-38; Csapo (2004b) $57-66$.

40 Thus Csapo (2004b) 60-1 on the basis of $I G^{3} 969$ from Anagyrus which lists tragic choreutai without patronymic and demotic.

41 Even if it was not theatrical in nature, attention must also be drawn in this context to the performance of Homer at the Panathenaea, which is a significant part of Athenian song-culture and has particular implications for the mythological and, broadly, intertextual aspects of theatrical competence: performances of drama and epic can indeed be said to feed off each other. On ephebic service and its implications for theatrical competence, see pp. 114 and 119 below.

42 Bacchylides 18 and Philoxenos' Cyclops come to mind; see Csapo (2004a) 215 and Sommerstein (2001) 156 with further literature.

$43 \Sigma$ on Aristophanes Birds 1392 quotes the proverb

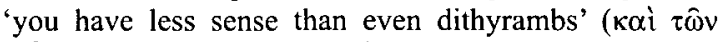

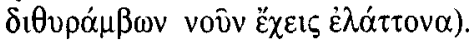




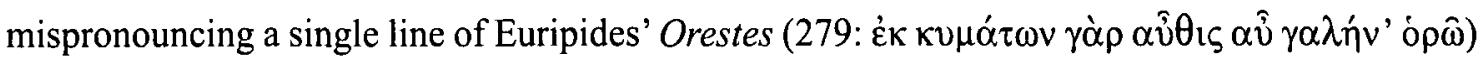
in such a way that the audience understood $\gamma \alpha \lambda \hat{\eta} v$ ('weasel') instead of $\gamma \alpha \lambda \eta \nu \alpha$ ('calm sea').44 What made the event so memorable and the ensuing ridicule so scathing and persistent? Audiences with the set of competence skills that the Athenian ones possessed not only instantly spot this sort of technical mistake, they also tend to be merciless in their judgement: this mistake ought not to happen in a contest, particularly not to the leading actor.

The second train of thought I wish to pursue is even simpler than the preceding one, and involves the set-up of the Athenian dramatic festivals. By the end of the five-day Great Dionysia a spectator who had attended all performances had been exposed to the pieces performed by twenty dithyrambic choruses, to five (or perhaps three) comedies (see n.23 above), nine tragedies and three satyr-plays. Beyond this, first-rate drama was accessible outside the Great Dionysia and the Lenaea at the many deme-festivals. ${ }^{45}$ Foreigners who flocked into Athens for the Great Dionysia would be able to see plays in their home-towns. Fifth-century drama is big business, a growing entertainment industry of its own.

What sort of theatrical competence is acquired by merely being exposed to performed drama for a substantial amount of time and with some frequency? Obviously, the concept 'expertise by exposure' is a rather dubious one. One can, to introduce an analogy, listen to the 48 preludes and fugues of Bach's Well-Tempered Clavier many times in a row. Nevertheless, there will, sooner rather than later, be a limit to the depth of understanding, which can be overcome only by studying the score, seeking historical and musical background information and so forth. But to dwell on this analogy for a short while: what sort of expertise is acquired by a listener without any specific musical background, provided only that he or she listens with interest, curiosity and attentiveness? Very early on, formal patterns will become apparent: the alternation of pieces of a somewhat free structure with pieces of a more rigorous nature in which a principal melody is played right at the start (i.e. the alternation between prelude and fugue); these principal melodies, it will soon be evident, recur in every other piece and seem to have a somewhat special status: they move in register and can be intertwined, shortened or lengthened; there is some recurrent change of mood between one set of interlude plus principal-melody pieces and another (that is the alternation of major and minor keys between consecutive sets of prelude and fugue); the listener will start to wonder how the principal-melody pieces and the interludes are related to one another, and even if the listener does not arrive at the right solution (the regulated shifts in tonality), he or she will nevertheless be reasonably sure that there is a pattern. In sum: the attentive listener will know quite a lot about the Well-Tempered Clavier and the structure of a fugue.

I have deliberately chosen this analogy. What makes it, I believe, particularly suited for my purpose is the degree of formalism, the strict adherence to formal patterns in conjunction with extensive variations within this form. ${ }^{46}$ It is remarkable to observe a similar formalism in Greek drama, even if not quite on the same scale as in the Well-Tempered Clavier. Great variations in tone, subject-matter, dramatic technique and characterization between the known playwrights should not obscure the immense formal conservatism of Athenian drama. Among other things, this finds its expression in the continued deployment of the chorus, and the ways in which its sung interludes are used to structure, support, interpret and reflect on the delineation of the plot; the use of eye-witness narratives and other stock-scenes and routines; the sequence of intruders in the post-parabatic parts of a comedy; the emergence of genre-specific closures and so forth.

44 Exploited by Aristophanes (Frogs 303-4), Sannyrio (fr. 8) and Strattis (frr. 1 and 63); see Willink (1986) 132.

${ }^{45}$ Csapo (2004b) 57-66.

46 The conventional structures of Greek drama are well studied, with Taplin (1977) and the essays collected in Jens (1971) providing the most wide-ranging discus- sions. In addition, note Bremer (1976) and de Jong (1991) on messenger speeches; Duchemin (1968), Lloyd (1992) and Dubischar (2001) on the tragic agon; Mastronarde (1979) 19-34 on proxemics; Hall (2002) on actor's monodies; Gelzer (1960) on the epirrhematic agon in comedy, and Hubbard (1991) on the parabasis. 
Developments and innovations happen within this framework of formal conservatism. Most interestingly, the developments themselves do not necessarily lead away from formalism. In the wake of the aesthetics of Romanticism, artistic development is often perceived as a 'dissolution' of form. Clearly such tendencies existed, particularly in the music of late tragedy (astrophic polymetrical songs). But note the sustained employment of highly formalized elements in both tragedy and comedy: symmetrically arranged debates in Euripides or the persistent use of fixed epirrhematic structures (parodos, agon and parabasis) in Aristophanes are cases in point. Frogs, the last comedy of the fifth century we have, is remarkably conservative in its formal features, with two choruses and an enormous epirrhematic agon at its centre. ${ }^{47}$

This startling formal conservatism of fifth-century drama has implications for the 'expertise by exposure' argument. The viewer of Greek drama will soon notice structural patterns: the importance of the chorus entry and its timing, for instance, which in the vast majority of cases happens at a fairly standard point (between 200 and 300 lines into the script, so roughly 10-15 minutes into the performance); the regular change of passages spoken by actors and choral songs in tragedy; the epirrhematic structures in comedy, particularly the importance of the parabatic break. Through frequent exposure the viewer will acquire competence with regard to costume, dance, acting style and delivery in tragedy and comedy and their genre-specific differences, however pronounced they may have been. 48 For people who have active theatrical experiences of their own - who have, to return to the original analogy, themselves played a prelude and a fugue at some point - the 'expertise by exposure' effect is much amplified. Other, prima facie nontheatrical activities, it must be added, can contribute to enhancing an individual's theatrical competence: because of their inbuilt theatricality and affinity to drama, activities such as participation in ritual, being part of a symposium or being subject to military training (notably marching in formation while singing) further refine the skill-set of the individual playgoer.

A discussion of 'expertise by exposure' would be incomplete without exploring the diachronic dimension of the phenomenon: exposure changes in quantitative and qualitative terms in the course of the fifth and fourth centuries, surely with (beneficial) consequences for theatrical competence. Drama, never a minor fixture of Greek performance culture, ${ }^{49}$ becomes ever more mobile and bigger business, culminating in the rise of migrant star performers who are active all over the Greek cultural continuum. ${ }^{50}$ Athens may be a prime example of sharply increasing demand for drama. For if the lower estimates of seating capacity for the fifth-century theatre that have recently been suggested are correct (see n.38), this would imply that in the so-called Lycurgan theatre, construction of which may have been begun as early as the $360 \mathrm{~s},{ }^{51}$ seating capacity was roughly doubled.

But it is not solely the case that more people watched drama. Tastes became more refined and demanding. Csapo observes a change of acting style towards greater 'realism' starting in the final quarter of the fifth century.52 This means a more nuanced use of sign systems (notably voice, language and gesture) for the representation of age, gender, ethnicity and class. In as competitive a theatrical environment as the Athenian one, such changes make sense only if there was heightened sensitivity of, even demand for, more refined modes of theatrical representation on the part of audiences. Similar inferences are to be drawn from the rise at around the same time of 'New Music', with its greater harmonic and rhythmical complexity. ${ }^{53}$ It will be noted that

47 On the structure of the rival-play The Muses by Phrynichus, notably its court scene, see Harvey (2000) 100-3.

48 Halliwell (1990).

49 Fundamental discussions of Greek performance culture and the place of drama in it are Herington (1985) as well as Goldhill and Osborne (1999).
50 Taplin (1999) 34-43; Easterling (2002) 331-3; Wilson (2002) 48-9 (on the mobility of aulos-players).

51 Goette (1999).

52 Csapo (2002).

53 Csapo (1999/2000) and (2004a). 
both phenomena, 'realism' and 'New Music', are strongly theatrical and performative rather than narrowly textual. They appeal, in other words, precisely to the kinds of skill-sets that are particularly fostered and developed by frequent exposure to drama and by choral participation.

\section{IMPLICATIONS}

Theatrical competence is an umbrella-notion for a complex set of sub-skills which are diverse in nature (horizontal axis) and can be mastered to different degrees (vertical axis). The shared competence of Athenian audiences, acquired through exposure to drama and enhanced by participation in dithyrambic or dramatic choruses, encompasses a strong sense of genre, in particular its visual markers, movements, a sense of theatrical space, delivery, melody, rhythm and fundamental structural markers such as epirrhematic or triadic modes of composition. This is what fifth-century playwrights can, and do, take for granted when subjecting their offerings to the evaluative power of diverse audiences (with élite and non-élite members) in competitive performance contexts.

Beyond this shared competence, making sense of drama is a process that is both stratified and highly individualized. The double-act of appealing to all while sustaining an individual's interest by means of activating and challenging the personal level of competence lies at the heart of successfully competing at the dramatic festivals. ${ }^{54}$ In this final section I wish to explore the rationale and the dynamics of this double-act by looking at cross-generic play (which is based on incongruency and de-familiarization) and parabatic inter-textuality. I will conclude by discussing the most famous passage to do with audience competence in extant Greek drama. All three case studies chosen relate to comedy. Since this genre is most overt in signalling theatricality and intertexts, it is the best indicator of the questions at stake, although the observations made of course apply to playgoing in general and exposure to all genres.

Thesmophoriazusae is a particularly rewarding test case. ${ }^{55}$ In its rich paratragic referentiality it may strike the modern interpreter, initially, as complex to an almost overwhelming degree, presupposing a universally competent audience in order to make sense. My fundamental point, however, is that this comedy is highly complex and sophisticated - and that it is not. The play works on many registers and is designed for stratified decoding by a diversified audience. It encapsulates, in an exemplary manner, what I earlier called the 'paradox of theatrical communication', applied to the competitive situation in Athens: while lending itself to analysis by the connoisseur, Thesmophoriazusae remains interesting, gripping and, most importantly, funny at lower levels of decoding. It has to, like every product of the fifth-century drama industry, for otherwise its very competitiveness in the market-place would be in danger.

Was it possible to miss the play's connectivity with Euripidean tragedy - the Telephus, Palamedes, Helen and Andromeda? Yes and no, because familiarity with these plays is invoked in different ways. The connection is hammered home for three of the four tragedies, at 769-70

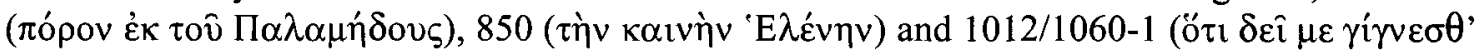

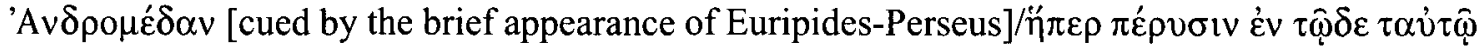

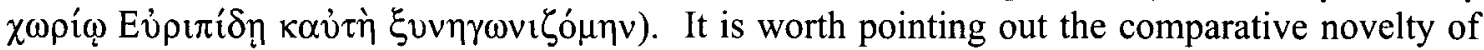

54 At the high end, were the judges 'models of competence'? Quite possibly so, even though it is impossible to be certain. A number of judges were nominated by each tribe before the festival, and it would seem natural that only those individuals would be put forward who were, or were thought to be, particularly suited to the task. On the selection procedure, see Marshall and Willigenburg (2004) 91-2 and Csapo and Slater (1995) 157-8.
55 Two plays the loss of which is sorely to be deplored in this context are Aristophanes' Gerytades (408?) with its reflections on tragedy, comedy and dithyramb, and the jewel of fifth-century comedy, Cratinus' Pytine (423). The latter has been of major interest to scholars recently: Sidwell (1995), Rosen (2000), Ruffell (2002) and Biles (2002). 
these theatrical experiences, explicitly mentioned in the case of Helen (produced in 412, together with the Andromeda, while the Palamedes dates back to 415). The strategy is evidently designed to get as many people as possible on board at a level of decoding which presupposes awareness of general plot-patterns and their de-familiarizing comic use.

This stratagem of outreach and inclusion by metatheatrical overtness and appeal to recent theatrical experience stands in sharp contrast to the handling of the Telephus (produced in 438), which, as has been noted, ${ }^{56}$ is woven into the play's texture in fundamentally different ways. Not only is there no explicit acknowledgement of the interface. More than that, the Telephus is inscribed at a level which extends beyond the hostage-taking (689-764). Rather than being an isolated episode, this signature-scene is but the culmination of cross-generic appropriation based on structural affinity: an intruder adopts a disguise in order to infiltrate a hostile assembly. Such plot-based appropriation, which comes with the Aristophanic addition of drag and cross-dressing, makes the question of when the Telephus-parody actually starts a blurred, even futile one. Note further that the structural affinity becomes fully apparent only with the hindsight of the hostage-taking scene which articulates a link that had been latently operative all along.

Two explanations, in principle, present themselves for this unflagged use, which is both structural and episodic in nature. One would be to assume that the Telephus is so much part of shared theatrical culture that it can be treated as a 'given', like the use of genre-specific masks, language or choreography. But attributing such a level of theatrical iconicity to any play, including a manifestly popular one like the Telephus, ${ }^{57}$ seems highly problematic. Also note that in Acharnians the (prominent) use of this Euripidean tragedy is clearly flagged (Ach. 430). To cope with the apparent paradox that the most recent theatrical experiences are overtly signalled while the integration of a 27-year-old play is more subtle and varied, a different mode of explanation suggests itself: inbuilt stratification. By choosing not to signal the Telephus connection Aristophanes widens the range and variety of possible responses. 'Getting it' becomes more of a challenge, hence a greater means of differentiation.

This does not mean that the three flagged instances of appropriation are straightforward to such an extent as to preclude any variety in the level of engagement. The Helen and Andromeda parodies both rely heavily on flattening Euripidean complexities. In the productions of the year 412, Euripides had indulged in his penchant for the ambiguous, obscure, unexpected, exotic, pathetic and spectacular, articulating himself in an expressive theatrical language which resorted to variety and contrast of costumes, deceitful disguise, spectacle and unusual aural effects. For Euripides, of course, these are tools for creating dramatic meaning. Aristophanes, however, isolates selected effects, thereby detaching them from the context within which they generate theatrical meaning. A play on the mismatch of appearance and reality, otherness and the limits of human intelligibility, Helen is dissected and transformed into a farce of swift recognition (899-911) before an uncomprehending female guardian, followed by an aborted rescue-attempt. In a similar vein, Euripides' spectacular echoing of Andromeda's voice - deployed to demonstrate the isolation, fear and despair of the virgin who, betrayed by all, is chained to a rock awaiting her doom - is deprived of its depth. By boldly materializing the stage effect and representing it as an old (1073) and comically uglified woman, Aristophanes trivializes it, exposing as empty and flashy what in its proper dramatic context made a significant contribution towards creating tragic pathos in the opening scene.

These are the sophisticated readings of the paratragic distortions. At the other end of the spectrum, both parodies make sense even to a spectator who has only the vaguest notions of Euripidean theatricality in general and the Andromeda- or Helen-stories in particular. The

56 Bowie (1993) 223-4; Austin and Olson (2004) lviii; see also Zeitlin (1996a) 387-99.
57 Taplin (1993) 37; Collard et al. (1995) 17-25; Preiser (2000) 41-63. 
bottom line is having a sense of tragic intrusion, which presupposes an awareness of the key visual and verbal markers of genre. The parodies are, in other words, completely lost on anyone who fails to recognize that the comic Euripides visually and verbally adopts tragic identities (with the comic identity continually shining through, so that the incongruity of Euripides trying to look like Perseus and Echo is readily apparent ${ }^{58}$ ). It is no accident that the internal audiences, Critylla and the Scythian archer, are precisely below this bottom line which debars them from engaging at any level with the generic cross-over. ${ }^{59}$ Ignorant of the fact that their counterparts increasingly model their comportment on tragedies, Critylla and the Scythian archer thus become an anti-audience, the butt of laughter of spectators who are united in their recognition of the paratragic dimension while being diversified in their individual appreciation of its layers.

Appealing to theatrical competence and integrating the audience by letting them feel they are 'in the know' had featured earlier in Thesmophoriazusae during Agathon's appearance. Key generic markers like costume and the ekkyklema are again pivotal, but what makes this scene particularly interesting is the kind of theatrical expertise which is prominently invoked. Launched as an innovator (52-62), Agathon is shown as composing a lyric duet between a chorus of maidens and their chorus leader. A celebratory hymn, the setting of which is most likely to be immediately after the Achaeans' supposedly final departure from Troy, the song of the deceived chorus and their false sense of joy and liberation are 'not a happy omen for Euripides' great plan'. ${ }^{60}$ Its astrophic metrical structure, consisting of a mix of ionic, choriambic and trochaic rhythms, is evidently designed to parody the antics of the 'New Music', even if the precise nature of this parody is impossible to determine for lack of suitable evidence, in particular from Agathon himself. ${ }^{61}$ The theatrical pitch, however, is clear: chorality and the nature of the 'New Music' are the two areas in which expertise is presupposed in order to make the parody intelligible. Both are, of course, precisely those fields in which, as has been argued here, the degree of shared competence among a contemporary Athenian audience was particularly high. The polarization and ideological rifts which the 'New Music' gave rise to at a time when the élite was fearing for its dominance in cultural politics and beyond ${ }^{62}$ should not obscure the fact that the 'New Music' was not at all on the fringe but a well-known and widely practised theatrical phenomenon. Those audiences that in the wake of comedy's cultural conservatism were made to laugh at vitriolic presentations of Cinesias and Phrynis (in Aristophanes' Birds and Eupolis' Demes respectively) are the same audiences that regularly witnessed this type of music in drama and dithyramb, helped to award prizes to its composers, or performed it themselves. While aesthetic and ideological responses surely differed on an individual basis, the spectators' level of alertness to the technicalities of this music as well as the politics surrounding its alleged 'newness' (greatly exaggerated, it seems, by its anxious critics) must have been considerable. This widely shared ability to relate on all levels turns the Agathon-scene into a showcase of how sophisticated a theatre is possible in an environment informed by frequent exposure and broad participation of this particular type.

\footnotetext{
58 Euripides is wearing a 'portrait' mask with caricature features. He is grey-haired and wearing a beard (190), as is confirmed by the Vita 1.12 Kovacs and the portraits of Euripides (Richter (1965) I.133-40). For his female rôles, then, the beard either had to be concealed or removed, the latter necessitating an off-stage change of mask. But even so, there would remain features which could let the Euripides-identity shine through persistently: parts of the clothing, the mere colour of the male mask, which is normally dark red as opposed to the white of female masks (Stone (1981) 22-7), and the grey hair with its conspicuous length and wildness as shown on the
}

portrait-sculptures. Euripides is also said to have had moles on his face (Frogs 1246-7, Vita 1.12 Kovacs:

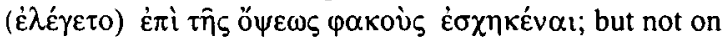
the portrait-sculptures) which seem to have been conspicuous and could be represented effectively on a mask, as was apparently done in Frogs.

59 This point is forcefully made for the Scythian archer by Hall (1989).

60 Austin and Olson (2004) on 101-29.

61 Parker (1997) 398-405; Austin and Olson (2004) 88-9.

62 These dynamics are explored by Csapo (2004a). 
Parabatic inter-textuality, my second focus, is tantamount to competence-activation at a high level. The demands made on audiences during these periods of self-advertisement, productplacement and metatheatrical reflections can be significant ones, presupposing knowledge of stock-scenes, rival playwrights and their plays, as well as the oeuvre of the poet himself. In this environment of genre-specific self-marketing, Aristophanes, when composing a new parabasis for the revised version of Clouds, probably had no choice but to acknowledge his defeat in the competition of 423 and present his own views on it rather than bypass the issue in silence, certainly if (as seems likely) he was envisaging a re-performance in Athens: his experienced audience simply would not be fooled. Establishing audience rapport, in other words, becomes even more subject to continuous renegotiation. Ruffell is surely correct to assume that inter-textuality of such complexity 'is predicated upon, indeed constructs, an intimacy and continuity between poet, performers and audience', generating an atmosphere which is informed by a 'dynamic where both the repetition and innovation have aesthetic value and add to the poet's reputation, as well as the audience's enjoyment'. ${ }^{63}$ The existence, nature and amount of comic inter-textuality considerably strengthen the argument in favour of frequent exposure to drama and the type of competence thus acquired. This is because the politics of self-positioning only make sense if conceived and articulated with a receptive spectator in mind who is capable of locating a plot, scene or individual joke within a nexus that encompasses genres (comedy, tragedy, satyr-play and dithyramb), play types, stock-scenes and the idiosyncrasies of individual playwrights precisely the skills acquired by frequent exposure, also bearing in mind that the inter-textual parabasis is not confined to Aristophanes but a widespread characteristic of the genre. ${ }^{64}$

It is, however, not a surprise that parabatic inter-textuality, like other forms of inter-textuality (including paratragedy), comes with inbuilt stratification as well as mechanisms which help prevent the worst-case scenario of losing a whole audience or a significant part of it. The most important of these is the simple fact that the parabasis is a somewhat detached and self-contained entity, the preserve of the choral voice, and a significant caesura (at least in the Aristophanic manifestation of Old Comedy). A dramatic pause as much as a structural break, no plot (at least in the preserved (Aristophanic) plays) is significantly affected by leaving out the parabasis. Little comic effect rests on them, and unlike the beginning or ending of a comedy the parabasis is not a 'make-or-break' situation for the competing playwright. During these parabatic 'timeouts', a spectator can easily switch off temporarily without experiencing a sense of lasting exclusion: there is always enough critical mass, so to speak, to keep the momentum high enough to ensure the universal appeal of the play as a whole. Like paratragedy, parabatic inter-textuality therefore manages to create 'win-win' situations for the playwright: providing appeal and challenge to the connoisseur without alienating someone who has only partial or even no grasp of the issues at stake. Similar points apply to more complex forms of inter-textuality involving the parabasis. If it is correct to assume that the plot of Cratinus' Pytine is a direct large-scale response to the polemics launched against him by Aristophanes in the parabasis of Knights, ${ }^{65}$ this does not undermine the play's comic effect on those spectators who are entirely unaware of the connection. While the ingenious self-comedification within a domestic allegory gains subtlety, originality and momentum if seen as a pointed response to Knights, Pytine (as far as we can tell) retains most of its comic force for someone who is entirely ignorant of Knights as a formative subtext.

My final remarks concern a passage which puts the competence issue most pressingly on the agenda, although it tends to be approached from the related, though different, angle of audience

63 Ruffell (2002) 155 and 162.

64 As is implied by Acharnians 628-9.

65 Ruffell (2002) and Biles (2002). Hubbard (1991) 126-39 regards the parabasis of Wasps as linked to the plots of both Knights and Clouds. 
literacy and the dissemination of books. This is the notorious antistrophe which is part of an interlude that structures the agon of Frogs (1109-18):

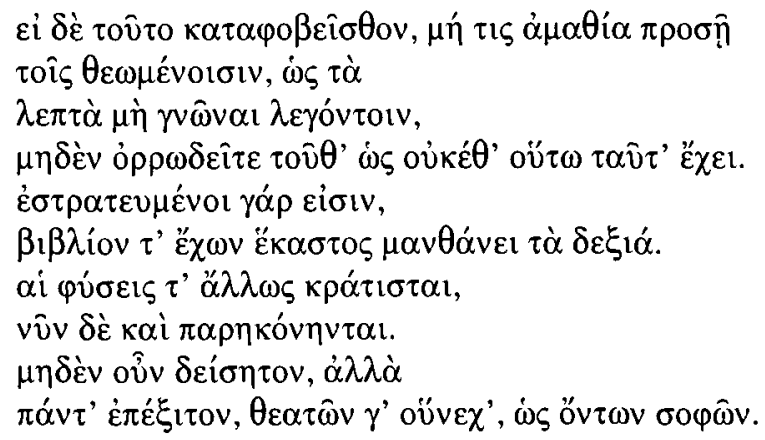

In case the two of you are afraid that there is some dullness among the spectators so that they do not understand the subtleties as you speak, don't worry about this at all. For this is no longer so. They are well-trained, each one of them holds a book in his hands and gets the refined stuff. Their pre-disposition is sturdy anyway, but now there is an added edge. So no reason to worry for the two of you: just tackle everything, for as far as the spectators are concerned, they are sophisticated.

As always, the rhetoric of 'there is no problem whatsoever' strongly suggests that there is, has been or might be one. This is corroborated by the seemingly inconspicuous 'for this is no longer

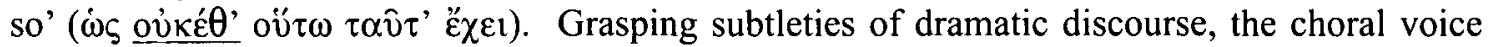
admits, is a competence that takes time to acquire. Of greater significance, however, is the fact that this sort of collectively shared expertise is something that can be safely assumed, now at any rate. Things, in other words, have changed - for the better. This is a remarkable statement from a playwright whose all-pervasive scepticism about the present is matched only by his idealization of the past, in accordance with a presumably genre-typical perception of an Athens in steady decline (and hence in need of comedy's advice). In an age of war, bad leadership and all-pervasive deterioration of a city in urgent need of her poet-saviour (the comic 'Aeschylus', and with him comedy in all its glory), could there possibly be anything that has become not worse but better? Self-advertisement, it may be argued, is what underlies this peculiar rhetoric of amelioration which culminates, implicitly, with the advent of Aristophanes on the theatre scene. Thus, a naïve and unsophisticated audience may be implied by the colourful phrasing of the parabasis of Knights, where Cratinus is said to have 'flowed through stoneless plains' (Knights 527: $\delta \mathrm{i} \alpha \hat{\omega} \mathrm{v}$ $\dot{\alpha} \varphi \varepsilon \lambda \hat{\omega} v \pi \varepsilon \delta i \omega v \varepsilon^{\prime} \rho \varepsilon \varepsilon$ ) before he found his successor, and (alleged) superior, in Aristophanes. To be sure, Aeschylus, according to the Euripides of Frogs, took over spectators from Phrynichus

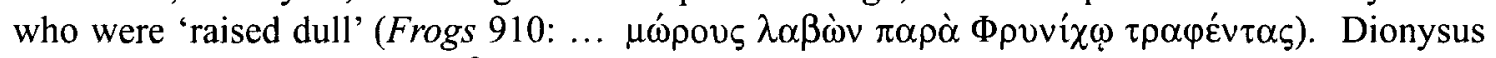
was 'stupid' (Frogs 917: $\dot{\eta} \lambda \hat{i} \theta$ los) when taking delight in Aeschylean silences, and it was the Euripidean introduction of domestic subjects that turned dumb theatregoers into competent

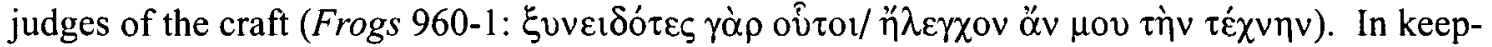
ing with this, Cratinus' coinage of the unpleasant 'Euripidaristophanizing' ( $f r .342$, see p. 102 and n.9) may be construed as an ironic response to a type of drama that poses as particularly novel and sophisticated.

But while it is true that Aristophanes, like the Euripides of Frogs, certainly regards his own artistic presence as a boon and maps himself onto the history of his trade accordingly, the gist of the passage in Frogs is a broader, less self-interested one. The well-trained audience is, after all, a commodity to be shared by every competing playwright. In this context, the military metaphor

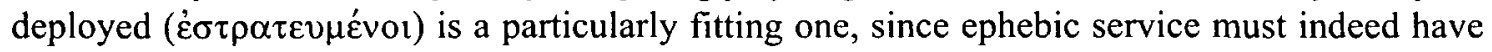
contributed a great deal to the acquisition of widely shared skills that would feed into common theatrical competence. Competence-acquisition of the theatrical sort, I submit, is of at least 
equal importance in this passage as the literacy-debate that the mention of the book $(\beta 1 \beta \lambda$ iov) in the hand of every spectator has fuelled. ${ }^{66}$ The argument over whether and how much this particular remark is to be considered tongue-in-cheek is unlikely ever to cease, and one may correspondingly wonder whether there is anything ironical about the claim of higher audience competence in general. But the case for taking the mention of increased competence at face value is a strong one. For, as has been argued earlier (at the end of section III, pp. 114-15), there is good reason to believe that theatrical competence was indeed on the rise precisely at the turn of the fifth to the fourth century. This corroborates the Aristophanic claim of the 'sharper edge' that

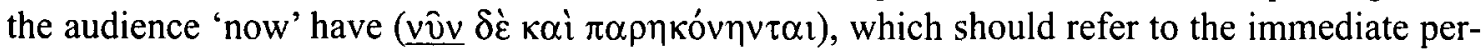
formative context and the ways in which audience awareness is heightened, and competence activated, during the actual theatrical event.

The encouragement appears to be needed, and the timing of these remarks is hardly fortuitous. Placed about half way through the enormous agon and its aftermath (871-1481), these remarks may be taken to function as a cheer-up of sorts. Also note that after this choral interlude the agon becomes more technical in nature (touching on opening technique, music and lyrics). The demands on audience competence in the agon are not small, even though, as usual, stratified appreciation is inbuilt. But is there a chance of losing the audience, or at least of the playwright fearing that this might be the case? When designing a play, it is vital to hit the right pitch, not least in the sort of competitive situation in which Aristophanes and his rivals constantly found themselves. Alertness to the sensitive issue of pitch and the danger of hyper-sophistication is most overtly expressed in the opening section of Wasps (64-6):

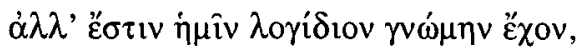

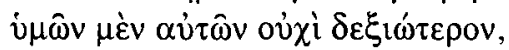

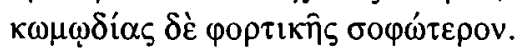

But we have a little story that is reasonable, not more sophisticated than you while being more refined than low comedy.

While under-challenged audiences may lose interest, there is an even greater danger in being over-challenging. As a rule of thumb, audiences of whatever description loathe being presented with something which simply goes over their heads, notably so if such over-pitching persists for a substantial period of time. Aristophanes, to be sure, did not lose his audience during the long agon of Frogs: the play's success ${ }^{67}$ would seem to be sufficient evidence for an audience who could follow, as a collective and for at least most of the time. But the need for flattering reassurance half way through the agon remains notable. It appears to be informed by the playwright's sense that here, of all places, audience rapport is in need of being reaffirmed, as he might be in danger of raising the bar too high and misgauging the nature of that vital yet sensitive bottom level of shared theatrical expertise.

MARTIN REVERMANN University of Toronto 34-5.

66 Harris (1989) 87; Lowe (1993) 68-9; Dover (1993)

67 It was granted a re-performance at one of the big Athenian festivals (Sommerstein (1993) 461-6 argues for the Lenaea of 404). The play's continued popularity is shown by the 'Berlin Heracles' crater from Apulia, dated to the second quarter of the fourth century, which is virtually certain to relate to a re-performance of Frogs, see Taplin (1993) 45-7. 


\section{BIBLIOGRAPHY}

Austin, C. and Olson, D. (2004) Aristophanes: Thesmophoriazusae (Oxford)

Barish, J. (1981) The Antitheatrical Prejudice (Berkeley)

Barsby, J. (ed.) (2002) Greek and Roman Drama. Translation and Performance (Stuttgart)

Biles, Z. (2002) 'Intertextual biography in the rivalry of Cratinus and Aristophanes', AJP 123, 169-204

Bowie, A. (1993) Aristophanes. Myth, Ritual and Comedy (Cambridge)

Bowie, E. (1998) 'Le portrait de Socrate dans les Nuées d'Aristophane', in Trédé and Hoffmann (1998) $53-66$

- (2002) 'Ionian iambos and Attic komoidia: father and daughter, or just cousins?', in Willi (2002) 33-50

Bremer, J. (1976) “"Why messenger-speeches?”, in Bremer et al. (1976) 29-48

Bremer, J., Radt, S. and Ruijgh, C. (eds) (1976) Miscellanea tragica in honorem J.C. Kamerbeek (Amsterdam)

Collard, C., Cropp, M. and Lee, K. (1995) Euripides. Selected Fragmentary Plays, 1 (Warminster)

Craik, E. (ed.) (1990) Owls to Athens. Essays on Classical Culture Presented to Sir Kenneth Dover (Oxford)

Cropp, M., Lee, K. and Sansone, D. (eds) (1999/2000) Euripides and Tragic Theatre in the Late Fifth Century (Illinois Classical Studies 24-5, Champaign)

Csapo, E. (1999/2000) 'Later Euripidean music', in Cropp et al. (1999/2000) 399-426

- (2002) 'Kallippides on the floor-sweepings: the limits of realism in classical acting and performance styles', in Hall and Easterling (2002) 127-47

- (2004a) 'The politics of the New Music', in Murray and Wilson (2004) 207-48

- (2004b) 'Social and economic conditions behind the rise of the acting profession in the fifth and fourth centuries BC', in Hugoniot et al. (2004) 53-76

- (forthcoming) 'The men who built the theatres: theatropolai, theatronai, and arkhitektones', in Wilson (ed.) (forthcoming)

Csapo, E. and Slater, W. (1995) The Context of Ancient Drama (Ann Arbor)

Culler, J. (1975) Structuralist Poetics (Ithaca)

Davies, M. (1998) 'Euripides' Electra: the recognition scene again', $C Q$ n.s. 48, 389-403

Dawson, S. (1997) 'The theatrical audience in fifth-century Athens: numbers and status', Prudentia 29, 1-14 Dearden, C.W. (1999) 'Plays for export', Phoenix 53, 222-48

de Jong, I. (1991) Narrative in Drama. The Art of the Euripidean Messenger-Speech (Leiden)

de Marinis, M. (1993) The Semiotics of Performance (Bloomington; orig. published in Italian, Milan 1982)

Dover, K. (1972) Aristophanic Comedy (Berkeley and Los Angeles)

- (1993) Aristophanes: Frogs (Oxford)

Dubischar, M. (2001) Die Agonszenen bei Euripides. Untersuchungen zu ausgewählten Dramen (Stuttgart and Weimar)

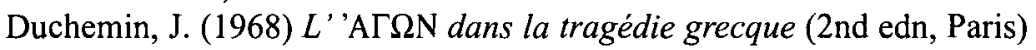

Easterling, P.E. (1994) 'Euripides outside Athens: a speculative note', ICS 19, 73-80

- (2002) 'Actor as icon', in Easterling and Hall (2002) 327-41

Easterling, P. and Hall, E. (eds) (2002) Greek and Roman Actors. Aspects of an Ancient Profession (Cambridge)

Ehrenberg, V. (1951) The People of Aristophanes. A Sociology of Old Attic Comedy (2nd edn, Oxford)

Elam, K. (2002) The Semiotics of Theatre and Drama (2nd edn, London)

Foley, H. (ed.) (1981) Reflections on Women in Antiquity (New York)

Gallagher, R. (2003) 'Making the stronger argument the weaker: Euripides, Electra 518-44', CQ 53, 401-15

Garnsey, P. (1998) Cities, Peasants and Food in Classical Antiquity. Essays in Social and Economic History, ed. with addenda by W. Scheidel (Cambridge)

Gelzer, Th. (1960) Der epirrhematische Agon bei Aristophanes (Munich)

- (1970) 'Aristophanes', RE Suppl. XII, 1392-1569

Goette, H. (1999) 'Die Basis des Astydamas im sogenannten lykurgischen Dionysos-Theater zu Athen', Antike Kunst 42, 21-5 
Goldhill, S. (1994) 'Representing democracy: women at the Great Dionysia', in Osborne and Hornblower (1994) 347-69

Goldhill, S. and Osborne, R. (eds) (1999) Performance Culture and Athenian Democracy (Cambridge)

Gould, J. and Lewis, D. (1988) The Dramatic Festivals of Athens (revised 2nd edn, with supplement and corrections, Oxford)

Green, J.R. (1994) Theatre in Ancient Greek Society (London and New York)

Griffith, M. (1995) 'Brilliant dynasts: power and politics in the Oresteia', Classical Antiquity 14, 6-129

Griffiths, A. (ed.) (1995) Stage Directions. Essays in Ancient Drama in Honour of E.W. Handley (BICS Suppl. 66, London)

Hall, E. (1989) 'The archer scene in Aristophanes' Thesmophoriazusae', Philologus 133, 38-54

- (2002) 'The singing actors of antiquity', in Easterling and Hall (2002) 3-38

Halliwell, S. (1990) 'The sounds of the voice in Old Comedy', in Craik (1990) 69-79

- (1998) Aristotle's Poetics (2nd edn, London)

Hansen, M. (1986) Demography and Democracy. The Number of Athenian Citizens in the Fourth Century B.C. (Herning)

Harriott, R. (1962) 'Aristophanes' audience and the plays of Euripides', BICS 9, 1-8

Harris, W.V. (1989) Ancient Literacy (Cambridge, MA and London)

Harvey, D. (2000) 'Phrynichos and his Muses', in Harvey and Wilkins (2000) 91-134

Harvey, D. and Wilkins, J. (2000) The Rivals of Aristophanes. Studies in Athenian Old Comedy (London)

Henderson, J. (1987) Aristophanes: Lysistrata (Oxford)

- (1991) 'Women and the Athenian dramatic festivals', TAPA 121, 133-47

Herington, J. (1985) Poetry into Drama. Early Tragedy and the Greek Poetic Tradition (Berkeley, Los Angeles and London) (Sather Classical Lectures 49)

Hubbard, T.K. (1991) The Mask of Comedy. Aristophanes and the Intertextual Parabasis (Ithaca and London)

Hugoniot, C., Hurlet, F. and Milanezi, S. (eds) (2004) Le statut de l'acteur dans l'antiquité grecque et romaine (Tours)

Jens, W. (ed.) (1971) Die Bauformen der Tragödie (Munich)

Kemal, S. and Gaskell, I. (eds) (1999) Performance and Authenticity in the Arts (Cambridge)

Knoepfler, D. (1993) Les imagiers de l'Orestie (Zurich)

Kowalzig, B. (2004) 'Changing choral worlds: song-dance and society in Athens and beyond', in Murray and Wilson (2004) 39-65

Lévy, E. (1976) 'Les femmes chez Aristophane', Ktèma 1, 99-112

Lloyd, M. (1992) The Agon in Euripides (Oxford)

López Férez, J. (ed.) (1998) La comedia griega y su influencia en la literatura española (Madrid)

Lowe, N.J. (1993) 'Aristophanes' books', Annals of Scholarship 10, 63-83

Luppe, W. (1972) 'Die Zahl der Konkurrenten an den komischen Agonen der Zeit des Peloponnesischen Krieges', Philologus 116, 53-75

- (2000) 'Ein weiteres Zeugnis für fünf Konkurrenten an den Komödien-Agonen während des Peloponnesischen Krieges', ZPE 129, 19-20

MacDowell, D. (1990) Demosthenes: Against Meidias (Oxford)

- (1995) Aristophanes and Athens. An Introduction to the Plays (Oxford)

Marchant, E. (1920) Xenophontis opera omnia, 5 (Opuscula) (Oxford)

Marshall, C. and Willigenburg, S. von (2004) 'Judging Athenian dramatic competitions', JHS 124, 90-107

Mastronarde, D. (1979) Contact and Discontinuity. Some Conventions of Speech and Action on the Greek Tragic Stage (Berkeley, Los Angeles and London)

Minwalla, F. and Solomon, A. (eds) (2002) The Queerest Art. Essays on Lesbian and Gay Theater (New York)

Morris, I., Saller, R. and Scheidel, W. (eds) (forthcoming) The Cambridge Economic History of the Graeco-Roman World (Cambridge)

Murray, P. and Wilson, P. (eds) (2004) Music and the Muses. The Culture of 'Mousike' in the Classical Athenian City (Oxford)

Osborne, R. and Hornblower, S. (eds) (1994) Ritual, Finance, Politics. Athenian Democratic Accounts presented to David Lewis (Oxford) 
Parker, L.P.E. (1997) The Songs of Aristophanes (Oxford)

Pelling, C. (ed.) (1997) Greek Tragedy and the Historian (Oxford)

- (2000) Literary Texts and the Greek Historian (London)

Podlecki, A.J. (1990) 'Could women attend the theater in ancient Athens?', Ancient World 21, 27-43

Prag, A. (1985) The Oresteia. Iconographic and Narrative Tradition (Warminster and Chicago)

Preiser, C. (2000) Euripides: Telephos. Einleitung, Text, Kommentar (Hildesheim, Zurich and New York)

Pritchard, D. (2000) 'Tribal participation and solidarity in fifth-century Athens: a summary', Ancient History $30,104-18$

- (2004) 'Kleisthenes, participation, and the dithyrambic contests of Late Archaic and Classical Athens', Phoenix 58, 208-28

Rau, P. (1967) Paratragodia. Untersuchungen zu einer komischen Form des Aristophanes (Munich)

Revermann, M. (1999/2000) 'Euripides, tragedy and Macedon: some conditions of reception', in Cropp et al. $(1999 / 2000) 451-67$

- (2005) 'The 'Cleveland Medea' calyx crater and the iconography of ancient Greek theatre', Theatre Research International 30, 3-18

- (2006) Comic Business. Theatricality, Dramatic Technique, and Performance Contexts of Aristophanic Comedy (Oxford)

Richter, G.M.A. (1965) The Portraits of the Greeks (3 vols, London; suppl. London 1972)

Römer, A. (1905) 'Über den litterarisch-aesthetischen Bildungsstand des attischen Theaterpublikums', Abhandlungen der Berliner Akademie der Wissenschaften 22, 1-95

Roselli, D. (2005) 'Vegetable-hawking mom and fortunate son: Euripides, tragic style, and reception', Phoenix 59, 1-49

Rosen, R. (1988) Old Comedy and the Iambographic Tradition (Atlanta)

- (2000) 'Cratinus' Pytine and the construction of the comic self', in Harvey and Wilkins (2000) 23-39

Ruffell, I. (2002) 'A total write-off: Aristophanes, Cratinus, and the rhetoric of comic competition', $C Q$ n.s. $52,138-63$

Scheidel, W. (forthcoming) 'Demography', in Morris et al. (forthcoming)

Scott, G. (1999) "The "poetics" of performance: the necessity of spectacle, music, and dance in Aristotelian tragedy', in Kemal and Gaskell (1999) 15-48

Seidensticker, B. (1996) 'Die griechische Tragödie als literarischer Wettbewerb', Berichte und Abhandlungen der Berlin-Brandenburgischen Akademie der Wissenschaften 2, 9-35

Sidwell, K. (1995) 'Poetic rivalry and the caricature of comic poets: Cratinus' Pytine and Aristophanes' Wasps', in Griffiths (1995) 56-80

Silk, M. (1993) 'Aristophanic paratragedy', in Sommerstein et al. (1993) 477-504

- (2000) Aristophanes and the Definition of Comedy (Oxford)

Solomon, A. (2002) 'Great sparkles of lust: homophobia and the antitheatrical tradition', in Minwalla and Solomon (2002) 9-20

Sommerstein, A. (1997) 'The theatre audience, the demos, and the Suppliants of Aeschylus', in Pelling (1997) 63-79

- (1998) 'The theatre audience and the demos', in López Férez (1998) 43-62

- (2001) Aristophanes: Wealth (Warminster)

Sourvinou-Inwood, C. (2003) Tragedy and Athenian Religion (Lanham)

Sommerstein, A. et al. (eds) (1993) Tragedy, Comedy and the Polis, Papers from the Greek Drama Conference Nottingham, 18-20 July 1990 (Bari)

Stone, L. (1981) Costume in Aristophanic Comedy (New York)

Storey, I. (2002) 'Cutting comedies', in Barsby (2002) 146-67

Storey, I. and Allan, A. (2005) A Guide to Ancient Greek Drama (Oxford)

Taplin, O. (1977) The Stagecraft of Aeschylus. The Dramatic Use of Exits and Entrances in Greek Tragedy (Oxford)

- (1993) Comic Angels and Other Approaches to Greek Drama Through Vase-Paintings (Oxford)

- (1999) 'Spreading the word through performance', in Goldhill and Osborne (1999) 33-57

- (ed.) (2000) Literature in the Greek and Roman Worlds. A New Perspective (Oxford)

Trédé, M. and Hoffmann, P. (eds) (1998) Le rire des anciens (Paris)

Wankel, H. (1976) Demosthenes. Rede für Ktesiphon über den Kranz (2 vols, Heidelberg) 
West, M. (1992) Ancient Greek Music (Oxford)

Willi, A. (ed.) (2002) The Language of Greek Comedy (Oxford)

Willink, C.W. (1986) Euripides: Orestes (Oxford)

Wilson, P. (2000a) The Athenian Institution of the Khoregia. The Chorus, the City and the Stage (Cambridge)

- (2000b) 'Powers of horror and laughter: the Great Age of drama', in Taplin (2000) 88-132

- (2002) 'The musicians among the actors', in Easterling and Hall (2002) 39-68

- (ed.) (forthcoming) Epigraphy of the Greek Theatre (Oxford)

Winkler, J. (1990) 'The ephebes' song: tragoidia and polis', in Winkler and Zeitlin (1990) 20-62

Winkler, J. and Zeitlin, F. (eds) (1990) Nothing to Do with Dionysus? Athenian Drama in its Social Context (Princeton)

Yunis, H. (2001) Demosthenes: On the Crown (Cambridge)

Zeitlin, F. (1996a) 'Travesties of gender and genre in Aristophanes' Thesmophoriazusae', in Foley (1981) 169-217. Revised and updated version in Zeitlin (1996b) 375-416 (quoted)

- (1996b) Playing the Other. Gender and Society in Classical Greek Literature (Chicago and London) 